RESEARCH PAPER

\title{
The Australian cigarette brand as product, person, and symbol
}

\section{S M Carter}

Objective: To examine, for dominant Australian cigarette brands, brand identity (overriding brand vision), brand positioning (brand identity elements communicated to the consumer), brand image (consumers' brand perceptions) and brand equity (financial value).

Design: Tobacco industry documents, articles from retail trade publications since 1990, and current brand advertising from retail trade publications were searched for information about Australian brands.

Results: Cigarette manufacturers benefit from their competitors' brand equity as well as their own. The industry sees Australian smokers as far less brand loyal and strongly oriented to "low tar". A few predominantly local brands dominate the market, with variation by state. Successful Australian brands exist in one of three categories: premium, mainstream, and supervalue. Their brand identity essence is as follows. Premium: quality. Mainstream: a good humoured "fair go" for ordinary Australians. Supervalue: value for money. All supervalue brand identities also include freedom, escape, mildness, an aspirational attitude, blue tones, and waterside scenes. Brand image and brand identity is frequently congruent, even when marketing is restricted, and brand image is generally more positive for a smoker's own brand.

Correspondence to: Stacy M Carter, School of Public Health, Room 128A Building A27, University of Sydney NSW 2006, Australia; carters@ health.usyd.edu.au
Conclusions: Tobacco control activities have undermined cigarette brand equity. Further research is needed regarding brand loyalty, low tar, and brand categories. Smokers may respond more positively to tobacco control messages consistent with the identities of their chosen brand, and brand-as-organisation elements may assist. Further marketing restrictions should consider all elements of brand identity, and aim to undermine brand categories.
$\mathrm{T}$ his paper discusses the cigarette brands that are currently important in the Australian market, and the process by which the tobacco industry has attempted to make those brands meaningful for consumers. Australia is a highly restricted marketing environment for tobacco brands. Federal Australian law has made most forms of tobacco marketing illegal, starting in 1976 and reaching a watershed in the (Federal) Tobacco Advertising Prohibition (TAP) Act $1992 .{ }^{1}$ On a background of existing television, radio and cinema bans, the TAP Act prohibited print advertising, domestic sponsorships and billboards, with some notable exceptions, particularly "internationally significant" sponsorships, which cease in 2006, and brand advertising in the retail trade press.

\section{The "brand"}

The "brand" is a fundamental, dominant, and constantly evolving concern in marketing. ${ }^{2-31}$ Despite agreement on the importance of "brands", what constitutes a "brand" is contested. ${ }^{14}$ Although the "brand" is sometimes defined simply as a "logo, trademark or package design",, 11121829 many authors emphasise that a brand is far more, particularly more recently and in resources for marketing practitioners. ${ }^{3} 4222528$

\section{Brand image}

In the 1950s and 1960s, marketing focused on concrete, novel product benefits, and the brand was considered to be merely an identifier..$^{71332}$ A highly original 1955 paper, "The product and the brand", ${ }^{16}$ posited that a "brand" was more: a complex symbol that built up a body of associations over time, and thus communicated ideas, attributes, image, character, and personality to consumers. With prescience, its authors foreshadowed a fundamental contemporary distinction between the product, a concrete object produced in a factory, and the brand, an abstract construct in the mind of the consumer which is independently important to sales." 8914162833 That paper inspired David Ogilvy to champion the idea of "brand image" or "brand personality" in the 1970s, often embodied as spokesperson characters for the brands he advertised. ${ }^{7}{ }^{17}$ The "brand image" concept is still important, now generally defined as the associations with or perceptions of the brand in the mind of consumers. ${ }^{45} 5111517$

\section{Brand positioning}

In the 1980s "positioning" rose to prominence. The "position" of a product was also a place in consumers" minds, but it was a place relative to competing products..$^{411} 12$ The "positioning statement" concept is still current in marketing, ${ }^{10}{ }^{12}{ }^{29}$ defined by Aaker as "the part of the brand identity and value proposition that is to be actively communicated to the target audience...[to] demonstrate an advantage over competitor brands". ${ }^{4}$ The value proposition is defined as "a statement of the functional, emotional and self-expressive benefits delivered by a brand that provide value to the consumer", ${ }^{4}$ and brand identity will be discussed shortly.

\section{Brand equity}

A dichotomy between "brands" and "commodities" underlies the brand concept. When consumers choose "commodities" they do so on the basis of price. ${ }^{39}$ Brand building is seen to liberate products from this dependence on price alone by creating lasting value in the mind of the consumer. ${ }^{3} 691120$ It is widely acknowledged that this added value, together

Abbreviations: BATA, British American Tobacco Australia Limited; PMI, Philip Morris International; PML, Philip Morris (Australia) Limited; TAP Act, Tobacco Advertising Prohibition Act; TPM, total particulate matter 
with a positive consumer experience of the product, can justify a price premium, influence sales levels, increase stock values, and improve profits. ${ }^{2-5} 9101920$

In corporate acquisitions in the 1980s huge prices began to be paid for brands, over and above the value of their manufacturing facilities. ${ }^{10}{ }^{11}$ This brought "brand equity", the financial value of brands, to prominence, a concept that became increasingly important in the 1990s. ${ }^{10}{ }^{15}$ Although there is much disagreement about how it should be measured, ${ }^{10}$ brand equity is seen to arise from other aspects of the brand, including brand awareness, brand imagery, brand loyalty, consumers' attitudes to the brand, perceived quality, brand associations, and patents and trademarks. ${ }^{3-5} 111^{12}$ It can be influenced by major new products, product problems, management changes, competitor actions, and legal actions. ${ }^{3}$

\section{Brand identity}

Later work emphasises the notion of a "brand identity", defined by the brand manager and determining all aspects of a brand's marketing. ${ }^{3}{ }^{10}$ Brand identity is complex and potentially arises from many elements (table 1 ). ${ }^{3}$ It is idealised, creative, and dynamic, a vision, purpose, and meaning for a brand, encapsulating the brand's values and determining the associations made with the brand. ${ }^{4}{ }^{10}$ Identity differs from brand image, which exists in the consumers' mind and is only partly determined by brand identity, and from positioning, which expresses only some aspects of a brand's identity and benefits. ${ }^{4}{ }^{10}$ Aaker identifies three parts of brand identity. "Brand essence" is "a single thought that captures the soul of the brand", what it is or what it does. Brand identity "core" consists of a few brand elements which summarise the brand's vision. Extended brand identity consists of "elements that provide texture and completeness". ${ }^{34}$

\section{METHODS}

This paper drew on three sources: tobacco industry documents, articles from retail trade publications, and brand advertising from retail trade publications.

Tobacco industry documents came from world wide web sites established following litigation in the USA. ${ }^{34}$ Documents came from the primary sites of cigarette manufacturers, ${ }^{35}$ the Council for Tobacco Research, ${ }^{36}$ and the US Tobacco Institute, ${ }^{37}$ and the secondary sites of Tobacco Documents Online (Bliley, BC, Health Canada and Guildford Miscellaneous collections), ${ }^{38}$ the Canadian Council for Tobacco Control site, ${ }^{39}$ the British Columbia Ministry of Health Services site, ${ }^{40}$ and the Center for Disease Control and Prevention Guildford site. ${ }^{41}$ The search string (pagewood or moorabbin or granville or australia or sydney or melbourne or brisbane or hobart or adelaide or perth or canberra or amatil or wills) has been used throughout the project to gather documents relating to the Australian market. Six hundred and ninety two of these, identified and annotated throughout the course of the project, contained information about Australian cigarette brands, including brand strategies, presentations, and consumer research. These are available from http://tobacco.health.usyd.edu.au/site/gateway/docs/research. htm. An overview of the approach to document searching and analysis used during the project is available elsewhere. ${ }^{42}$

The three main trade journals-Australian Retail Tobacconist, Retail World, and Australian Service Station and Convenience Store News (pre November 2001)/Australian Convenience Store News (post November 2001) were searched by hand. Searching started from 1990 because the brand makeup of the Australian market changed enormously at that time and the aim of this paper was to explore brands which are currently important in Australia. All articles and corporate advertisements that mentioned tobacco products or companies were copied. A particularly important source was the ACNielsen review of the top 100 brands in the Australian grocery market published annually in Retail World, which provides a brief description of brand positioning. In addition, all advertisements placed by Philip Morris Limited (PML), British American Tobacco Australia Limited (BATA) or Imperial Tobacco Limited for ready made cigarettes in the same retail journals between January 2001 and June 2003 were colour copied. This information was only analysed quantitatively, tabulating the occurrence of advertisements across the three publications, the number of pages they occupied, their place in the journal (cover or page number), and whether they featured a brand variant labelled "light", "mild" or $\leqslant 8 \mathrm{mg}$ tar.

The aim was to understand the Australian cigarette brand identities from the tobacco industry's point of view, thus a materialist, intersubjective position guided analysis. ${ }^{43}{ }^{44}$ All text sources were used the same way: information about Australian brands was annotated verbatim, organised chronologically, and then grouped iteratively into emergent themes. This paper is not an exhaustive explanation of brands in the Australian market, but a condensed reflection of the information opportunistically available from industry and retail sources.

\section{RESULTS}

\section{Brand loyal}

While Australian cigarette brand loyalty exceeds loyalty to other product brands, Australian smokers are seen to be less brand loyal than, for example, US or UK smokers. Industry documents from the 1970s to the 1990s state that the Australian market is volatile and characterise Australian smokers as both commonly smoking more than one brand and readily switching brands. ${ }^{45-49}$ A 2002 BATA advertisement in Retail World, solely intended to convince shopkeepers to minimise out-of-stocks, supports this notion: the most

Table 1 Potential components of brand identity. Adapted from Aaker ${ }^{4}$

\begin{tabular}{|c|c|c|c|}
\hline \multicolumn{4}{|c|}{ Elements of brand essence, core identity, and extended identity } \\
\hline Brand as product & Brand as organisation & Brand as person & Brand as symbol \\
\hline $\begin{array}{l}\text { Association with product } \\
\text { class (e.g. cigarettes) }\end{array}$ & $\begin{array}{l}\text { Organisation attributes } \\
\text { (e.g. innovation, } \\
\text { trustworthiness) }\end{array}$ & $\begin{array}{l}\text { Personality (e.g. feminine, } \\
\text { rugged) }\end{array}$ & $\begin{array}{l}\text { Visual imagery and } \\
\text { metaphors }\end{array}$ \\
\hline $\begin{array}{l}\text { Product attributes } \\
\text { (e.g. taste) } \\
\text { Quality/value } \\
\text { Uses } \\
\text { Users }\end{array}$ & Local versus global & $\begin{array}{l}\text { Brand-customer relationships } \\
\text { (e.g. friend) }\end{array}$ & Brand heritage \\
\hline Country of origin & & & \\
\hline
\end{tabular}


dramatic warning BATA could muster, based on their "general consumer survey", was that $43 \%$ of smokers would go elsewhere if their regular brand variant was out of stock, $28 \%$ would reportedly buy a different variant, and $22 \%$ a different brand. ${ }^{50}$ Although not directly comparable, findings from other markets, such as an American finding that only $9.5 \%$ of smokers switched brands in a year, ${ }^{51}$ suggest that Australian brand loyalty may be relatively low.

\section{Regional variation}

The Australian market is highly regionalised. To quote David Metcalf of WD\&HO Wills (Wills, member of the British American Tobacco Group): "it varies by state... Australia is really amazing-it's almost like separate countries." ${ }^{\prime 52}$ Although this makes market research more difficult, it also provides marketing opportunities. ${ }^{47534}$ Apart from Escort, which has approximately one quarter of the convenience market in South Australia but a negligible share in other states, ${ }^{55}$ the same few brands occupy different positions in the share data for different states. In the convenience market in the last quarter of 2002, for example, Winfield was the leading brand in Western Australia, NSW, and Victoria, with $35.0 \%, 34.0 \%$, and $25.1 \%$ value share, respectively, but was third in Queensland at $18.9 \%$ and fifth in South Australia with $9.0 \% .^{55}$ In 1986, Sydney, the biggest city market, was characterised as image based, rejecting deep discounting; Melbourne, the next biggest, as value based, responding more positively to discounting, although this pattern is not clear in current brand share data. ${ }^{56}$

\section{Local branding}

Since the 1970s successful brands have been those, like Winfield, Peter Jackson, and Longbeach, which were given distinctly Australian brand identities, and by the mid 1980s the local industry formally recognised that Australian smokers were resistant to international brands. ${ }^{57-61}$

\section{Diversification within existing brand families}

Another fundamental phenomenon in Australia has been increasing mildness. The "low TPM segment" has been a priority for Australia since the mid 1970s because it attracts "health conscious smokers", enhances quality perceptions, and assists smokers to deal with the declining social acceptability of smoking. Over time "mildness" has become essential to Australian brands, and is most acceptable when provided as a line extension-that is, a new variant of an existing product under the same brand..$^{125362-77}$ Frequently "mildness" is expressed not just through variant names, but through pack changes, generally through the use of paler and/or bluer colour.

By the early 1990s, industry documents referred to the Australian market as the "mildest in terms of average delivery", ${ }^{73}$ and to the "dramatic downward shift of $\mathrm{T} / \mathrm{N}$ (tar/nicotine) deliveries of Australian products" dynamic" of the market. ${ }^{73} 75$ By 1994, Henry Goldberg of PML argued: "for some years now, there have been three kinds of new products launched in Australia; mild extensions; price propositions; and failures. We don't intend to launch a new price brand unless provoked. Not surprisingly then, we have plans for even lower tar versions of all of our major brands.,"78

Australian brand identities thus needs to be particularly robust, capable of resonating through up to eight or 10 variants. Machine-read tar is objectively relatively meaningless because smokers are able to compensate to adjust for product design changes, ${ }^{79}$ and the industry's own consumer research showed that smokers had minimal understanding of what "low tar" actually meant. ${ }^{66}$ However, industry research also showed that smokers experienced "lowered tar" as a real sensory phenomenon, influenced in part by the brand family
Table 2 Brands currently being advertised in the Australian retail trade press

\begin{tabular}{|c|c|c|}
\hline & International brand & $\begin{array}{l}\text { Predominantly Australian } \\
\text { brand }\end{array}$ \\
\hline Premium & $\begin{array}{l}\text { Benson \& Hedges; Dunhill } \\
\text { Kent* (stand alone "low } \\
\text { tar" }^{\prime \prime} \text { ); Lucky Strike*; } \\
\text { Marlboro; Peter Stuyvesant; } \\
\text { West* }\end{array}$ & Alpine (stand alone menthol) \\
\hline Mainstream & & $\begin{array}{l}\text { Escort (South Australia); } \\
\text { Peter Jackson; Winfield (now } \\
\text { exported) }\end{array}$ \\
\hline Supervalue & & $\begin{array}{l}\text { Holiday; Horizon; } \\
\text { Longbeach; Stradbroke }\end{array}$ \\
\hline
\end{tabular}

*Currently minimal brand share

th most instances in Australia functional benefits such as mentholation or "low tar" are offered as line extensions within existing brand families. Stand alone products are distinct brands positioned on such a functional benefit.

and the tar band printed on the pack. ${ }^{80}$ Manufacturers raced to lower the tar banding of their important brands both to maintain loyalty by enabling trade-down over time within one brand family, and to attempt to steal share from competitor brands by getting to a "tar point" first. ${ }^{77} 81$

Other Australian tobacco control research confirms that, in the current market, when a brand moves into a lower pack count, for example, it tends to do so in a wide range of tar variants. $^{82}$ Retail trade publications show that the $5-8 \mathrm{mg}$ "medium" tar band currently has the highest share and is the industry's priority. Line extensions in recent years have included B\&H Lights 6 (1997); Marlboro Medium (8 mg, 2001); and Winfield Light Blue Special Mild 6 (2003), and supervalue products offer vast "lights" choice: Longbeach, for example, is in Filter, Mild, Super Mild, Ultra Mild, Ultimate, $1 \mathrm{mg}$, Menthol, and Menthol $2 \mathrm{mg}$. Retail trade publication advertising is dominated by images of packets of cigarettes labelled "light", "mild" or $8 \mathrm{mg}$ tar or below, even when the advertisements are for the entire brand family. What was once "low tar" is an increasingly "regular" offering, reinforcing "mildness" as an intrinsic brand characteristic.

\section{Premium, mainstream, supervalue}

The Australian cigarette market is far simpler than the complex matrix of brands available internationally. ${ }^{83}$ In supermarkets, for example, 10 brands account for about $95 \%$ of volume. ${ }^{84}$

Australian brands belong to one of three categories, commonly termed premium, mainstream, and supervalue. Wills called them "premium, value and commodity" and characterised them as: "image, image/value, and value/ image" ${ }^{\prime 9} 7885$ Supervalue are sold primarily in packs of 30 , 40 , or 50, mainstream and premium brands in packs of 30 , 25 , or $20 .{ }^{50} 86$ The three categories were slowly constructed through competitive attacks and in response to perceived consumer preferences between the early 1970s and the introduction of the Tobacco Advertising Prohibition Act in 1992.

Table 2 presents the major Australian brands of ready made cigarettes. Mainstream brands have the largest market share in both the convenience and the grocery sector. After mainstream brands, premium does better in convenience shops and supervalue in grocery shops.* A similar skew is seen in the targeting of advertising to retail trade publications, although for high profit premium brands there are

*Based on data from Retail World Annual Report 2001 and Australian Convenience Store News March/April 2002 Tobacco feature. 
more advertisements overall, and more double page and cover advertisements.

\section{The premium segment}

The premium segment contains Australia's oldest brands, mostly major international brands. They are targeted at younger, more urban, higher income consumers who care more about image than price and are more likely to buy in packs from convenience stores than cartons from grocery stores, and also to the mainstream smokers who use them as supplementary brands. ${ }^{87}$

The common element of the premium core brand identity is quality. ${ }^{71} 78$ 88-92 As Aaker notes, ${ }^{34}$ "quality" and "value" are inextricably linked, and premium brands offer quality rather than value-they are typically sold at high price in a small pack. "Quality" is seen in brand-as-symbol and brand-aspersonality elements as well as brand-as-product elements such as taste. ${ }^{91}$

Australia is a "priority market" for Benson\&Hedges $(\mathrm{B} \& \mathrm{H})$, which dominates the premium segment. ${ }^{93}$ The $\mathrm{B} \& \mathrm{H}$ core brand identity is "gold", communicated especially through the pack. ${ }^{71}{ }^{88-91} \mathrm{~B} \& \mathrm{H}^{\prime}$ ' "gold" identity is strongly reflected in its brand image, and aligns the brand to the premium brand essence of quality.

Alpine's core brand identity, in addition to the brand essence of quality, is "fresh clean femininity". ${ }^{76} 92$ This is strengthened by brand-as-product, brand-as-symbol, and brand-as-person elements. Alpine's users are young, feminine, white collar (or not working) women. ${ }^{89} 9294$ Alpine is mentholated and has white tipping and a green and white pack..$^{7189} 92$ It also has a heritage of "escapist" promotional imagery starring a young, free, and attractive woman going on a five star beach holiday. ${ }^{71} 8992$

Consumer research commissioned by the industry shows that premium brand images match their identities and positioning. Both Dunhill and B\&H are perceived as classy, stylish, up-market and top quality, ${ }^{49}{ }^{95} \mathrm{~B} \& \mathrm{H}$ as clever/smart with status, non-elitist but aspirational, ${ }^{90}{ }^{91}$ Dunhill as exclusive/elitist. ${ }^{91}$ The maintenance of B\&H's "gold" heritage tells B\&H smokers "I'm OK, you're OK" in the face of the declining social acceptability of smoking. ${ }^{91}$ Alpine is perceived as milder, cleaner, less harmful, and more "healing" than non-menthol cigarettes. Its image also has strong brand-asperson elements. Alpine is "feminine", "upmarket", "sophisticated", and signifies "balanced success as women" to its smokers. Alpine benefits from a relationship with its smokers that provides "emotional gratification", relaxation, "regaining control and confidence", "looking and feeling attractive", and "temporary escapism.",71 92

\section{The mainstream segment}

Although a range of price offerings had been available in Australia from at least the 1960s, ${ }^{62} 698996$ the late 1970s saw a major shift towards "good value" in the Australian cigarette market, internationally unprecedented in size and scope.$^{73}$ "Good value" was seen to incorporate price, imagery, and product elements, including perceived quality. ${ }^{89}$ Tobacco industry analysts have said that Australian consumers see "the same quantity for less money" as "decreased quality", instead demanding more quantity for the same money. "The US generic approach of low price/low image product has never been successful in Australia. Discount for quantity purchase is a pre-requisite for success. This belief is reflected

tInternationally, in the mid 1980s, there was a move "away from classical image based brands to a wide variety of value for money offers" in cigarette marketing. ${ }^{97} 98$ Australia is not the only market to have experienced a value orientation, but the mid 1970s Australian shift was notable for its size and scope at the time. across the entire consumer perishables segment.."73 8996 In 1983 an international consultant observed that this added value approach seemed to remove the stigma from smoking cigarettes that cost less per stick. ${ }^{69}$

The mainstream cigarette category was created by two new, successful brands, Winfield (25s) and Peter Jackson (30s), which capitalised on the Australian smokers' desire for more for the same price. Larger packs offered the manufacturers economies of scale and also increased smoker's consumption. ${ }^{73}{ }^{99}$ The mainstream brand essence was: a good humoured "fair go" for ordinary Australians. The category brand identity thus contained quality/value elements (a fair go), user elements (for ordinary Australians), and personality elements (egalitarian good humour). ${ }^{6988} 89100101$

Both brands fore grounded "a fair go" in their positioning, Winfield as " 5 smokes ahead of the rest" ( 25 cigarettes rather than 20), ${ }^{102}$ and Peter Jackson as "30 of the best at a popular $25 \mathrm{~s}$ price", and later "Best value in Australia". ${ }^{103-105}$ Both emphasised full or added length to further this positioning. This value emphasis was supported by "intense image development program[s] to obtain smokers' loyalty and resilience to competitor initiatives" ${ }^{\prime 73}{ }^{102}$ which included elements of brand as product, person, and symbol.

Winfield's brand-as-person element, a cheeky "Aussie bloke", was provided by the actor Paul Hogan. ${ }^{102}{ }^{106} \mathrm{He}$ starred in Winfield's humorous advertising campaigns throughout the 1970s, advising "anyhow, have a Winfield", with a calm grin, in the context of bizarre, challenging, or hopeless situations. This was welcome advice in a context of recession and youth unemployment. ${ }^{106}$ Accordingly, Winfield's smokers were younger, slightly more male, and of lower socioeconomic status: Winfield was particularly "for those starting to smoke". ${ }^{106}$ Although Hogan was removed from the advertisements in 1980 on the grounds that he appealed to children, the strong association meant that he continued to be a high profile "walking advertisement for Winfield", 89 and longstanding "Winfield Cup" sponsorship of Rugby League football helped sustain the masculine Aussie personality of the brand.

Peter Jackson's mainstream Aussie humour was communicated through the tag "Peter Jackson: you're laughing". ${ }^{103-105}$ Its brand identity included a quality edge, intended to be communicated through pack, advertising, premiums, and event promotions. ${ }^{48} 7881101104107$ The brand relied heavily on associations with motor racing, ${ }^{75}{ }^{76} 105$ but also softened brand-as-symbol elements over time to become less aggressive and masculine and further differentiate from Winfield.$^{66} 78$

Mainstream brand image has varied. In the 1980s smokers agreed that Winfield was lesser quality than premium brands in consumer research, ${ }^{88}{ }^{106}$ but Winfield's own smokers saw it as a "respectable", value for money brand, mirroring the brand's identity. ${ }^{106}$ Premium smokers, in contrast, emphasised poor quality, seeing Winfield as smaller, looser, cheap, with a "burning" taste, and found Winfield's symbols "unattractive". ${ }^{106}$ In the 1990s, Winfield smokers described their own brand to be higher quality than Peter Jackson.95 Supervalue smokers characterised mainstream cigarettes as "everyday" but also as out of their league because they were "quality" brands, not far behind premium brands. ${ }^{85} 95$ In 1993 these smokers still linked Winfield to Paul Hogan, describing the brand as "quality, Paul Hogan, average bloke-cheeky, Australian" and Peter Jackson as "average bloke, standard, cigarette machine, Australian". ${ }^{85}$

\section{The supervalue segment}

The success of mainstream offerings plateaued in the late 1980s, undermined by growing pack sizes that created a new category dubbed "supervalue". ${ }^{103}$ Packs of 35 and 40 grew to $20.5 \%$ of the market in 1988/89, first with Stradbroke and 
then with Longbeach as the first full specification 40s product. ${ }^{73}$ Holiday was the first 50s in 1991, followed by Horizon as the first full size 50s. PML attributed the rise of supervalue to increasing taxation, and the fact that "the aggressive activity of the anti-smoking lobby ha[d] impacted significantly on the social acceptability of smoking, which ha[d] in turn diluted considerably the traditional benefits of an image platform for brands" ${ }^{\prime \prime} .{ }^{73}$ In addition, manufacturers had been prioritising market share over profitability, "diluting the value of trademarks through a focus on value, which can easily be duplicated or surpassed by competitors, as opposed to consolidation of image providing a unique value (i.e. not price) to the trademark. This has been reflected by switching rates-over 33\% of Australian smokers are now switching within a 12 month period. This problem is likely to be exacerbated by draconian restrictions..." ${ }^{173}$

Documents from this period resonate with the general dichotomy in the marketing literature between "brands" and "commodities", expressing fears that without effective brand building and in the presence of price discounting, Australian cigarettes could become commodity items. ${ }^{47}{ }^{108-111}$ Premium and mainstream brands were suffering and it was feared that the trend might spread to other countries. ${ }^{111}{ }^{112}$ Rothmans, manufacturer of Winfield, had a 33\% profit decline in 1990/ 91, and a further decline of $70 \%$ in 1991/92, ${ }^{113}$ and Rothmans' competitors were exasperated with its apparent disregard for brand equity. ${ }^{111}{ }^{113}$ Despite Winfield being a major competitor for the brands of Philip Morris (Australia) Limited (PML), Henry Goldberg, PML's managing director, was extremely concerned about the erosion of Winfield's brand equity and price position, and concluded "any increase in legitimate market expenditure by Rothmans would be a welcome return to them re-building brand equity". ${ }^{111}$

Despite the dangers, the trend culminated in a "damaging and peculiarly Australian price war", ${ }^{78}$ which was financially unsustainable for the industry. ${ }^{7414}$ The fact that larger pack sizes further increased individual smoker consumption ${ }^{73}$ was poor compensation for the tiny margins on large packs and the loss of smokers from brands with larger margins. Wills' Horizon 50s, launched in 1991, had zero margin. ${ }^{48}$ Although the companies developed the technology to produce 60s and 65s, ${ }^{48} 49111$ it was not used-by 1993 supervalue growth had flattened, and the $5 \%$ per annum decline in mainstream and $1.5 \%$ per annum decline in premium had stopped. ${ }^{111}$ However, the damage to premium brand equity was considered lasting. ${ }^{75}$

The shared essence of supervalue brand identities, the key to their positioning, and the prime motivation of their users, was value for money, and pricing was a vital component of the brands' marketing strategies. ${ }^{78}{ }^{115}$ Supervalue users were older, more female, poorer, and heavier and longer term smokers, who purchased from grocery stores. ${ }^{85} 115$

However, the industry saw the value for money essence as an insufficient basis for long term supervalue brand equity. ${ }^{75} 76$ Thus brand-as-person and brand-as-symbol elements were created. These were intended to have "an attitude of freedom, escape [and] mildness" and to be aspirational. ${ }^{103}{ }^{115-117}$ Blue tones were used, and waterside scenes implying escape to the freedom and relaxation of the water's edge, ${ }^{75}$ 85 $^{115-117}$ resonating with Australian grand narratives of beachside summer holidays and coastal retirements. The tag for Longbeach, "You're miles ahead", presented against scenes of long deserted beaches, exemplified the link made between the brand identity essence of "value for money" and the core brand identity element of waterside escape and freedom. ${ }^{48} 103117$ Because supervalue brands were launched close to the introduction of the TAP Act, this positioning has relied heavily on the point of sale and the pack. ${ }^{76} 85$
Brand image information from market research done by the tobacco industry showed a clear division between supervalue brand smokers and non-supervalue brand smokers. Smokers of all brands saw supervalue as "budget" brands. ${ }^{49}{ }^{85}$ Non-supervalue smokers saw them as thin, poortasting cigarettes, not value for money, and only attractive in terms of price. ${ }^{95}$ Winfield smokers defined supervalue brands as "not Winfield" and therefore "no name" (the Australian colloquialism for generic brands). ${ }^{95}$ Non-supervalue smokers also described the brands as "cheap looking" and did not respond positively to the classic supervalue symbols of beach scenes. They described supervalue smokers as immature, bland, wimpy surfers, and effeminate. ${ }^{95}$

In contrast, supervalue smokers saw the brands as being reasonable quality for the price, providing "more for your money", 95 and supervalue users as happy, relaxed, easygoing, an "aussie lifesaver", popular, outgoing, male or female, and importantly, as someone who looks for quality and value and "beats the system". ${ }^{95}$ Supervalue smokers described the beach symbols as a drawcard, as empathetic, desirable, appropriate to the brand, and providing space, freedom, relaxation, and contentment. ${ }^{95}$ Supervalue smokers also seemed to view their own brand in a disproportionately positive light, describing them as "not shrunken", flavoursome, easy to smoke, well priced, "the best of the big packets", and popular..$^{95}$ Longbeach smokers saw Longbeach as better quality than mainstream brands or other supervalue brands. ${ }^{95}$ Horizon smokers saw their brand's personality as "a seductive woman walking along the beach", calm, relaxed, and "floaty." ${ }^{85}$ Holiday had a poor brand image with Horizon smokers, seen as bad quality, "cheap and nasty", "loud/busy/ noisy" and thin, and Holiday users were "people who can't afford smokes" and "street kids". ${ }^{85}$

\section{Brand failure: Marlboro in Australia}

As a BATCo marketing intelligence department document observed in 1994, "there are virtually no markets, excluding Australia...where Marlboro has failed."118 In 1976, the year Winfield was launched, Marlboro had a $12.5 \%$ brand share, and 55\% of Marlboro smokers were under 25. By 1989 Marlboro had only $2.7 \%$ share and only $11 \%$ under 25 , despite PML's sacrifice of profit margins to try to bring it back. $^{89} 119$ It remained PML's "biggest problem" throughout the 1980s and 1990s, despite high brand awareness and consumers reporting that it was a cigarette "for Australians". ${ }^{101}$ The failure has been attributed to the success of mainstream, supervalue, and low tar; Marlboro's strong flavour and smell, atypical of Australian blends; and inconsistent and inappropriate brand positioning, including the Marlboro Man, seen by some Australian audiences as a cultural imperialist. ${ }^{101} 119$

Attempted solutions between 1980 and 2000, with close involvement from PM Corporation, ${ }^{119}{ }^{120}$ were focused on increasing the flow of teenage starters to the brand, and addressed elements of brand-as-product, brand-as-person, and brand-as-symbol. They included PMI almost immediately taking over advertising (imposing the American cowboy, considered a "mistake"), ${ }^{121}$ importing US soft packs (1983), ${ }^{122}$ decreasing pack size (1984), ${ }^{123}$ and "making the advertising appealing to younger smokers who are in the process of forming brand preferences" (1984). ${ }^{123}$ There was also an attempt to change the blend to "make it harder for existing smokers to leave the product" ${ }^{\prime 23}$ Project Classic, a relaunch of the original 20s as a cult, individualistic, "Fully imported from the USA" brand also did little, despite being designed by Leo Burnett, the advertising agency responsible for the Marlboro Man. ${ }^{119}$

By 1993 PM were so desperate that, along with another modified blend and an "Australian version of Marlboro 
Country [to try to] rebuild Marlboro's big brand image", Marlboro's price was lowered to parity with Winfield, effectively putting Marlboro in the mainstream segment in terms of price, and potentially undercutting any aspirations to the premium essence of "quality". It continued to "behave like one of the minor, unsupported brands". ${ }^{78}$ As always with Marlboro, Philip Morris is prepared to wait. Growth has been slow and inconsistent, with share still minimal at grocery stores but up to $5 \%$ at convenience stores. ${ }^{24} 86$

\section{DISCUSSION}

Brand equity is a shared strength and weakness of the tobacco industry. A market consisting of robust brand identities with strong, positive brand images is the industry's assumed ideal, creating a more profitable market for all competitors. Equally, even unilateral undercutting of brand equity risks the introduction of an entirely price based commodity market. The Australian market has settled into three brand categories, premium, mainstream and supervalue, each having a "brand essence" which is shared by its members. Brands within these categories have additional core brand identities that make them more or less distinct from one another. The failure of Marlboro in Australia may be at least in part due to its poor fit with Australian brand categories, as it lacks both the quality essence of premium and the good humour, value, and ordinary Aussie user associations which form the essence of mainstream.

All of the brand identities discussed in this paper were created before the introduction of the TAP Act in 1992, although the various supervalue brands had only one to three years to establish themselves via print, billboard, and radio advertising, and have thus relied almost entirely on point of sale and the pack for positioning. However, brand image research conducted by the industry after the introduction of the TAP Act showed striking congruence, for successful brands, between brand identity and brand image. As noted in the introduction, brand images are created cumulatively over time. Thus consumers' perceptions are likely to be based both on current marketing through available channels, and the brands' historical associations (exemplified by Paul Hogan still being linked to Winfield in smokers' minds 13 years after he was removed from the brand's advertising).

It is also clear that brand image is relative-the perceptions of smokers of supervalue brands differ substantially from those of premium brand smokers. This suggests some fundamental differences in the ways in which different smokers approach and choose between cigarette brands: that particular brand identities may resonate for particular smokers. Brand management principles can be applied to any communicative task, and brand identity elements may have potential for use in quit messages or media advocacy. Premium smokers may particularly respond to the brand-asproduct element of quality. Mainstream smokers may appreciate familiar user elements (for ordinary Australians) and personality elements (egalitarian good humour). Both mainstream and supervalue smokers may respond to the idea of a "fair go" or "value for money". Supervalue smokers may prefer symbol and personality elements of waterside escape, relaxation, freedom, and aspiration.

This potential could be further explored through research, as there are many questions not answered here. How loyal are Australian smokers? How distinct are the smokers of the three brand categories? Are smokers meaningfully differentiated by their brand choices? How do smokers relate to cigarette brand identities? Could the elements of these identities be used to destabilise commitment to smoking? Might smokers respond to different quit messages, as they have responded to differences in branding? Given that mildness is an inherent trait of successful brands, could

\section{What this paper adds}

The Australian tobacco industry's brand management strategies have not been explored in the tobacco control literature.

This paper introduces a framework for understanding how brands work, and applies it to successful Australian cigarette brands. Unique aspects of the Australian cigarette market include low brand loyalty, strong preference for low tar, and the existence of three distinct brand categories. An understanding of how brands operate in the market could assist tobacco control efforts to further undermine Australian cigarette brands.

accurate information about "low tar" cigarettes be a particularly effective quit communication in Australia? Given the success of local, "Aussie" brands, could the multinational nature of the industry be a useful frame for reducing the industry's social acceptability?

This raises a glaring gap in Australian cigarette brand identities: brand-as-organisation. Aaker proposes that characteristics of the organisation, such as innovation, trustworthiness, or its local/global character, can be used as brand identity elements. ${ }^{34}$ However, Australian cigarette brand positioning is relatively silent on this point. Australian consumer research has suggested that consumer trust in general is declining, creating a more critical and vigilant audience for brands that demands that products and the businesses behind them live up to their brands' identities. ${ }^{21}$ Anti-corporate activists have been using the brand-asorganisation element in their campaigns for years, associating Nike with Asian sweatshops rather than athletic tenacity, for example, or Starbucks with global and local market thuggery rather than the creation of community. ${ }^{28}$

A common means to subvert brand identities is via adbusting-modification of existing brand advertising such as billboards. Adbusting was important to Australian tobacco control before the TAP Act, ${ }^{124}$ and could still be of benefit in other markets, but is no longer relevant in Australia's restricted advertising environment. However, both traditional advocacy and culture jamming via the media and other channels could be used to creatively subvert brand positioning and to link brands to company activities incongruous with that brand's identity (for example, to highlight the profits made on the popular, supposedly "good value" mainstream brands). Communication could also be customised by brand: pack inserts, cardboard wraps around the pack, and health warnings are all existing communication channels that could potentially be utilised.

The Australian industry has acknowledged that tobacco control activities have seriously undermined brand equity in the cigarette market, not least by regulation of tobacco marketing. This work demonstrates the complexity of brand identities, and that brand image lives on in consumers' minds after the introduction of restrictions of above-the-line marketing. Brand image is tenacious and is far more than a simple trademark, incorporating elements such as user associations and longstanding relationships between smokers and their brands. Brand-as-product, brand-as-person, and brand-as-symbol elements should be considered in regulating cigarette marketing. Obvious remedies are the removal of point of sale marketing and the introduction of generic packaging, but even generic packs, if offered in the three existing brand categories, and particularly if they can be readily linked to previously existing brands, are likely to benefit from historic brand identities. It may be that existing brand identities will live on until a restructured generic cigarette market can be introduced. 


\section{ACKNOWLEDGEMENTS}

Thanks to reviewers for helpful comments and Fiona Byrne for indispensable information management. The research reported in this paper was supported by grants from the National Health and Medical Research Council (2001-2003 \#153857) and the US National Institutes of Health (2001-2005 \# R01 CA87110-01Al).

\section{REFERENCES}

1 Commonwealth of Australia. Tobacco Advertising Prohibition Act. Commonwealth Consolidated Acts, 1992. http://www.austlii.edu.au/au/ legis/cth/consol_act/tapa1992314/index.html (Accessed 14 Jul 2003)

2 Anholt S. Brand new justice: the upside of global branding, 1 st ed. Oxford: Butterworth-Heinemann, 2003.

3 Aaker D, Joachimsthaler E. Brand leadership, 1st ed. London: Free Press Business/Simon \& Schuster, 2000

4 Aaker D. Building strong brands, 1st ed. New York: The Free Press/Simon \& Schuster, 1996.

5 East R. Consumer behaviour: advances and applications in marketing, 1st ed. Hemel Hempstead Herffordshire: Prentice Hall Europe, 1997.

6 Myers G. Ad worlds: brands, media, audiences, 1st ed. London: Arnold/ Hodder Headline, 1999.

7 Ries A, Trout J. Positioning: the battle for your mind, revised 1st ed. New York: McGraw Hill, 1986.

8 Ries A, Ries L. The 22 immutable laws of branding, 1st ed. New York: Harper Business, 1998.

9 Weilbacher W. Brand marketing: building winning strategies that deliver value and customer satisfaction, 1 st ed. Lincolnwood, Illinois: NTC Business Books, 1993.

10 Kapferer J. Strategic brand management: creating and sustaining brand equity long term, 1st (English) ed. London: Kogan Page, 1997.

11 Aaker D. Managing brand equity: capitalising on the value of a brand name, 1 st ed. New York: The Free Press, 1991.

12 Kotler $\mathrm{P}$, Adam S, Brown L, et al. Principles of marketing, 1 st ed. Frenchs Forest: Pearson Education Australia, 2001

13 Dowling G. Corporate reputations: strategies for develoing the corporate brand, 1st ed. Melbourne: Longman Professional, 1994.

14 Ind N. The corporate brand, 1 st ed. London: MacMillan Business, 1997

15 Rook D. Products and brands. In: Rook D, ed. Brands, consumers, symbols \& research: Sidney J Levy on marketing, Thousand Oaks, California: Sage Publications, 1999:127-9.

16 Gardner B, Levy S. The product and the brand (1955). In: Rook D, ed. Brands, consumers, symbols \& research: Sidney J Levy on marketing. Thousand Oaks, California: Sage Publications, 1999:131-40.

17 Levy S. Imagery and symbolism (1973). In: Rook D, ed. Brands, consumers, symbols \& research: Sidney J Levy on marketing. Thousand Oaks, California: Sage Publications, 1999:233-40.

18 Rossiter JR, Ang L. Brand equity building for new brands via appropriate advertising symbol selection. Sydney: Australian Graduate School of Management, UNSW, 1992.

19 Mackay Research. Creating customer loyalty. Lindfield: Mackay Research Pty Ltd, 1992.

20 Mackay Research. Brands \& generics, Lindfield: Mackay Research Pty Ltd, 1993.

21 Mackay Research. The meaning of brands. Lindfield: Mackay Research Pty Ltd, 1998

22 Peters T. The brand cafe. Tom Peters Company 2003. http:// www.tompeters.com/brand_cafe/ (Accessed 10 Sep 2003)

23 ACNielsen. 1998/99 ACNielsen Top 100 Brands. AC Neilsen, 2001

24 ACNielsen. 2002 Annual Report. Retail World 2002; Dec:32.

25 BuildingBrands Ltd. Buildingbrands website. 2003. http:// www.buildingbrands.com/ (Accessed 22 May 2003)

26 Gabriel Y, Lang T. The unmanageable consumer: contemporary consumption and its fragmentations. London: SAGE Publications, 1995.

27 Kerslake D. ACNielsen Top-100 Brands 2000. Sydney: ACNielsen, 2000

28 Klein N. No logo. London: Flamingo/HarperCollins, 2001.

29 Rossiter JR, Percy L. Advertising communications and promotions management, 2nd ed. Boston, Massachusetts: Irwin/McGraw-Hill, 1997.

30 TrueNorth Consultants. What is a brand? TrueNorth Strategies 2003 http://www.truenorthconsultants.bigstep.com/generic9.html (Accessed 28 May 2003)

31 van den Berg A. Brand Power Lives! A C Neilsen 22 Nov 2001. hitp:// www.acnielsen.com.au/news.asp?newsID $=143$ (Accessed 14 July 2003)

32 McCarthy E. Basic marketing: a managerial approach, 1 st ed. Homewood, Illinois: Richard D Irwin, 1960.

33 Ambler T. Marketing from advertising to zen, 1st ed. London: FT Pitman Publishing, 1996.

34 Malone RE, Balbach ED. Tobacco industry documents: treasure trove or quagmire? Tobacco Control 2000:9:334-8.

35 Tobacco manufacturers' document websites. http://www.pmdocs.combin/rsasearch.asp; http://www.bw.aalatg.com/public.asp; http:// www.lorillarddocs.com/cgi-bin/rsasearch.asp; http://www.rirtdocs.com/ rirtdocs/index.wmt?tab = home

36 Council for Tobacco Research document website. http://www.ctr-usa.org/ $\mathrm{ctr} /$ index.wmt?tab $=$ home

37 Tobacco Institute document website. http://www.tobaccoinstitute.com/cgibin/Rsasearch.asp

38 Tobacco Documents Online. Smokescreen Corporation. http:// tobaccodocuments.org/
39 Canadian Council for Tobacco Control tobacco documents site. http:// www.ncth.ca/Guildford.nsf

40 British Columbia Ministry of Health Services tobacco documents site http://www.moh.hnet.bc.ca/cgi-bin/guildford_search.cgi

41 Center for Disease Control and Prevention, Guildford tobacco documents site.. http://www.cdc.gov/tobacco/industrydocs/index.htm

42 Chapman S, Byrne F, Carter SM. "Australia is one of the darkest markets in the world": the global importance of Australian tobacco control. Tobacco Control 2003;12(suppl III):iii]-3.

43 Potter W. An analysis of thinking research about qualitative methods, $1 \mathrm{st}$ ed. Mahwah New Jersey: Lawrence Erlbaum Associates Publishers, 1996.

44 Silverman D. Doing qualitative research: a practical handbook, 1 st ed. London: SAGE publications, 2000.

45 Gordon DL. Notes on Australian presentation. 1978. Brown \& Williamson. Bates No. 659007501/7504. http://legacy.library.ucsf.edu/tid/ bpql $4 f 00$

46 Robinson W. William Robinson Management Consultant. Australian cigarette market. 12 Jul 1983. Brown \& Williamson. Bates No. 670500220/ 0221. http://legacy.library.ucsf.edu/tid/ziy04f00

47 British American Tobacco. [Wills Market Research]. [1985]. British American Tobacco. Bates No. 102699794/9822. http:// tobaccodocuments.org/health_canada/10269979.html (Accessed 10 Jul 2003)

48 Philip Morris (Australia) Limited. [Operating budget and market forecast]. 1992. Philip Morris. Bates No. 2504204085/41 19. http:// legacy.library.ucsf.edu/tid/ahn32e00

49 Yann Campbell Hoare Wheeler. W.D.\& H.O. Wills Packaging Research Study: qualitative report. Nov 1994. British American Tobacco. Bates No. 500245336/5406. hitp://tobacco.health.usyd.edu.au/tds/ BAT500245336_5406 (Accessed 10 Jul 2003)

50 British American Tobacco Australasia. [Advertisement]. Retail World 2002; (April 15-26).

51 Cummings KM, Hyland A, Lewit $E$, et al. Discrepancies in cigarette brand sales and adult market share: are new teen smokers filling the gap? Tobacco Control 1997;6:S38-43.

52 Swanton L. Tighter laws drive cigarette company creativity. Australian Service Station and Convenience Store News 1998;May/Jun:38-9.

53 British American Tobacco. BATCo Operating Group five year plan, 19901994. Jan 1990. British American Tobacco. Bates No. 502640954/1045. http://tobaccodocuments.org/health_canada/2239.html (Accessed 14 Jul 2003)

54 British American Tobacco. [BATCo company plan report excerpt]. [1991] British American Tobacco. Bates No. 502630615/0641. http:// tobaccodocuments.org/health_canada/2250_01.html (Accessed 14 Jul 2003)

55 No author. Tobacco regulation review. Australian Convenience Store News 2003; (Jan/Feb):30.

56 Philip Morris International. Market Research Seminar, September 1986. Volume IV. Sep 1986. Philip Morris. Bates No. 2504006457/6709. http:// legacy.library.ucsf.edu/tid/eka42e00

57 Kummel E, Maxwell H. Introduction of Hamish Maxwell by Eugene Kummel and remarks by Hamish Maxwell Chairman and Chief Executive Officer Philip Morris Companies Inc. 16 Oct 1989. Philip Morris. Bates No. 2501452970/2996. http://legacy.library.ucsf.edu/tid/cwr39e00

58 Philip Morris International. Minutes from Wednesday, June 20 presentations International Trademarks. 20 Jun 1990. Philip Morris. Bates No. 2500114157/4167. http://legacy.library.ucsf.edu/tid/ygd42e00

59 Miller T. Marketing intelligence report: competitive activities. 2 Jan 1985. R.J. Reynolds. Bates No. 504591758/1764. http://legacy.library.ucsf.edu/ $\mathrm{tid} / \mathrm{ewh} 65 \mathrm{~d} 00$

60 British American Tobacco. Project Cloudburst: note to the BAT Industries PLC Board [excerpt]. [1993]. British American Tobacco. Bates No. 201073875/ 3881. http://tobaccodocuments.org/guildford_misc/2010738693881.html (Accessed 14 Jul 2003)

61 Burgess G. BATCo plan preview [Memo to all BATCo directors forwarding meeting minutes]. 16 Nov 1993. British American Tobacco. Bates No. 502637786/7793. http://tobaccodocuments.org/health_canada/ 2234_002.html (Accessed 14 Jul 2003)

62 Cullman H. Philip Morris International five year plan, 1975-1979. Jul 1974. Philip Morris. Bates No. 2048148837/8989. hitp:// legacy.library.ucsf.edu/tid/izs81 foo

63 WD \& HO Wills (Australia) Limited. A review of and recommendations on passive smoking and social acceptability of smoking. Jul 1976. Brown \& Williamson. Bates No. 690013482/3502. http://legacy.library.ucsf.edu/ tid/ulx93foo

64 Australia. 1977. Brown \& Williamson. Bates No. 660904286/4292. http://legacy.library.ucsf.edu/tid/gci70f00

65 Hurley H. Gallagher International Limited. [Letter to H. Hurley re Silk Cut]. 16 Sep 1977. Philip Morris. Bates No. 2504077138/7139. http:// legacy.library.ucsf.edu/tid/mpi29e00

66 Colmar Brunton Research. Low tar cigarettes presentation prepared for Philip Morris Ltd. Jul 1993. Philip Morris. Bates No. 2504104805/4892. hitp://legacy.library.ucsf.edu/tid/own32e00

67 Evans L, Harmsma O. Project Commonwealth. 2 Jun 1983. Philip Morris. Bates No. 2074867705/7706. http://legacy.library.ucsf.edu/tid/dpv17d00

68 RJ Reynolds Tobacco International. Australia 1981 operating plan. Sep 1980. R.J. Reynolds. Bates No. 505525649/5653. http:// legacy.library.ucsf.edu/tid/kol15d00

69 The Australian market and some 1981 brand news. 1981. Brown \& Williamson. Bates No. 620746149/6153. http://legacy.library.ucsf.edu/ $\mathrm{tid} / \mathrm{mqw} 21 \mathrm{fOO}$ 
70 Australian cigarette market. 1984. Brown \& Williamson. Bates No. 675147695/7710. http://legacy.library.ucsf.edu/tid/ryk73f00

71 Philip Morris (Australia) Limited. Project Circe creative brief. 19 Mar 1987 Philip Morris. Bates No. 2504076301/6314. http:// legacy.library.ucsf.edu/tid/bbh29e00

72 British American Tobacco. Research Policy Group Meeting, September 19th-21 st, 1988, Salzburg, Austria. 20 Oct 1988. British American Tobacco. Bates No. 401018120/8132. http://tobaccodocuments.org/ bc moh/10535.html (Accessed $10 \mathrm{Jul}$ 2003)

73 Philip Morris. Value segment synopsis: the Australian market. Mar 1990. Philip Morris. Bates No. 2048568608/8613. http:// legacy.library.ucsf.edu/tid/inn36e00

74 Allen W. Summary of meetings held with Rothmans, Australia on February 24, 1993. 4 Mar 1993. R.J. Reynolds. Bates No. 516413407/3408. http:// legacy.library.ucsf.edu/tid/qny82d00

75 Philip Morris International. Philip Morris Asia/Pacific three year plan, 1992-1994. Dec 1991. Philip Morris. Bates No. 2500064000/4226. http://legacy.library.ucsf.edu/tid/wwil9e00

76 Philip Morris. [Presentation notes - slides 1-73 Australian retail market: notes for a NY Marketing Meeting]. 1992. Philip Morris. Bates No. 2504107172A/7192. http://legacy.library.ucsf.edu/tid/dii29e00

77 Philip Morris. Positioning paper-Project Alpha. 6 Jun 1991. Philip Morris. Bates No. 2504107057/7061. http://legacy.library.ucsf.edu/tid/ cii $29 \mathrm{e} 00$

78 Goldberg H. 1994 second revised forecast presentation, June 1994, New York. May 1994. Philip Morris. Bates No. 2504204001/4063. http:// legacy.library.ucsf.edu/tid/ygn32e00

79 King W, Carter SM, Borland R, et al. The Australian tar derby: the origins and fate of a low tar harm reduction programme. Tobacco Control 2003; 12(suppl III):iii61-70.

80 Philip Morris. Consumer panel test number 1. Jul 1993. Philip Morris. Bates No. 2057092037/2040. http://legacy.library.ucsf.edu/tid/soj96e00

81 Philip Morris. 1991 original budget: Marketing Presentation October 3 1990. Oct 1990. Philip Morris. Bates No. 2504107139A/7171. http:// legacy.library.ucsf.edu/tid/aii29e00

82 Scollo M, Younie S, Wakefield M, et al. Impact of tobacco tax reforms on tobacco prices and tobacco use in Australia. Tobacco Control 2003;12(suppl II):ii59-66.

83 RJ Reynolds. Competitive analysis. 12 Sep 1995. RJ Reynolds. Bates No. 519900759/0799. http://legacy.library.ucsf.edu/tid/dgw66d00

84 Anon. Tobacco category review. Retail World 2001;54(Nov 26-Dec 7):11-13.

85 Colmar Brunton Research. Slim cigarettes presentation prepared for Philip Morris Ltd. Aug 1993. Philip Morris. Bates No. 2504104402/4471. http:// legacy. library.ucsf.edu/tid/kio32e00

86 Anon. Focus stock selection within tightening regulations. Convenience Store News 2002;(Mar/Apr):18-21.

87 British American Tobacco. Establishing and implementing a communications strategy [includes a case study on Benson \& Hedges in Australia]. 1990. British American Tobacco. Bates No. 303625613/5641. http://tobacco. health.usyd.edu.au/tds/BAT303625613 5641 (Accessed 10 Jul 2003)

88 RJ Reynolds Tobacco International. Australia 1980 Business Plan. Sep 1979. RJ Reynolds. Bates No. 505525644/5648. http:// legacy.library.ucsf.edu/tid/jol15d00

89 WD \& HO Wills (Australia) Limited. Value for money marketing in Australia. [1983]. Brown \& Williamson. Bates No. 621707306/7370. http:// legacy.library.ucsf.edu/tid/fid70f00

90 Hirii T. B\&H gold standard: Project MIDAS [Memo to BATCo executives forwarding meeting notes and a presentation on testing methods]. $2 \mathrm{Apr}$ 1992. British American Tobacco. Bates No. 400057755/7767. http:// tobaccodocuments.org/guildford_misc/400057754-7771.html (Accessed 10 Jul 2003).

91 E Chris Adams Research Pty Ltd. Evaluation of three alternative advertising approaches for Benson and Hedges: a qualitative research report prepared for WD \& HO Wills (Australia) Limited and its advertising agency 'The Campaign Palace'. Jul 1992. British American Tobacco. Bates No. 303523430/3469. http://tobaccodocuments.org/health_canada/ 03800728.html (Accessed 14 Jul 2003).

92 Colmar Brunton Research Qualitative research Alpine creative presentation prepared for Philip Morris. Mar 1994. Philip Morris. Bates No. 2504102678/2701. http://legacy.library.ucsf.edu/tid/vii29e00

93 British American Tobacco. Benson and Hedges long term strategy. 1992. British American Tobacco. Bates No. 502568037/8040. http:// tobaccodocuments.org/health_canada/50256803.html (Accessed 10 Jul 2003).

94 Barber K, Sharrock S. Morgan consumer review, April-June 1994. Aug 1994. Philip Morris. Bates No. 2504103801/3908. http:// legacy.library.ucsf.edu/tid/jio32e00

95 Sweeney B. Brian Sweeney and Associates (Australia). Presentation Longbeach research study no. 7727. Sep 1992.Philip Morris. Bates No. 2504204122/4136. http://legacy.library.ucsf.edu/tid/bhn32e00

96 Hirii T. Value-for-Money Marketing Brand Development Course, Egham Surrey, 29th April-12th May 1984 [includes WD \& HO Wills (Australia) Limited presentation]. 12 May 1984. British American Tobacco. Bates No. 102245184/5197. http://tobaccodocuments.org/health_canada/ 10224518.html (Accessed $10 \mathrm{Jul} 2003$ )

97 British America Tobacco. The worldwide cigarette market: past, present future. 1984. Brown \& Williamson. Bates No. 512106481/6488. http:// legacy.library.ucsf.edu/tid//nr24fOO

98 British American Tobacco. Overview of Philip Morris' marketing strategy. 5 Feb 1985. British American Tobacco. Bates No. 500098281/8283. http:// tobaccodocuments.org/health_canada/02400434.html (Accessed 10 Jul 2003)

99 Webster $\mathbf{P}$. World Tobacco. Limiting factors in changing cigarette pack sizes, and, Changing a cigarette pack without losing face. Dec 1985. British American Tobacco. Bates No.102573668/3678. http:// tobaccodocuments.org/health_canada/01400322.html (Accessed $10 \mathrm{Jul}$ 2003)

100 BATCo Marketing Intelligence Department. World cigarette market trends 1985. Dec 1985. British American Tobacco. Bates No. 303594867/4921. http://tobaccodocuments.org/health_canada/R1661.html (Accessed 10 Jul 2003)

101 Snitzer M. Visit to Australia-September 11-14, 1984. 18 Sep 1984. Philip Morris. Bates No. 2023265668/5675. http://legacy.library.ucsf.edu/tid/ jmr98e00

102 Philip Morris. Marlboro megabrand management discussion. 3 Jan 1991. Philip Morris. Bates No. 2045125592/5663. http:// legacy.library.ucsf.edu/tid/ker81 foo

103 Philip Morris International. [State of play presentation]. 29 Aug 1989. Philip Morris. Bates No. 2500106406/6522. http://legacy.library.ucsf.edu/tid/ pnc42e00

104 British American Tobacco Company Marketing Intelligence Department Philip Morris Incorporated competitor activity report. March 1985. Brown and Willamson. Bates No. 516003073/3167. hitp:// legacy.library.ucsf.edu/tid/wdw23f00

105 Webb W. 1989 PMI board presentation-Asia/Australia. 29 Aug 1989. Philip Morris. Bates No. 2500106384/6391. http:// legacy.library.ucsf.edu/tid/czl19e00

106 Philip Morris (Australia) Limited. [Competitive intelligence information on Winfield cigarettes]. Nov 1986. Philip Morris. Bates No. 2500131194/ 1213. http://legacy.library.ucsf.edu/tid/tpc42e00

107 Snyder R. Philip Morris Asia and Australia. 1984. Philip Morris. Bates No. 2500106859/6915. http://legacy.library.ucsf.edu/tid/snc42e00

108 JJ Speakman \& Associates. Marketing communications. Jun 1990. British American Tobacco. Bates No. 303625567/5573. http:// tobacco.health.usyd.edu.au/tds/BAT303625567_5573 (Accessed 10 Jul 2003)

109 Bramley B. [Importance of quality on brand goodwill: presentation delivered at the BAT Marketing Conference, November 19-23, 1991]. 20 Nov 1991. British American Tobacco. Bates No. 202235487/5533. http:// tobaccodocuments.org/health_canada/20223548.html (Accessed 24 Jun 2003)

110 Philip Morris International. Minutes from Thursday, June 21 presentations "Marketing restrictions". 21 Jun 1990. Philip Morris. Bates No. 2500114168/4176. http://legacy.library.ucsf.edu/tid/zgd42e00

111 Goldberg H. Downside for 1993. Apr 1993. Philip Morris. Bates No. 2071284407/4426. http://legacy.library.ucsf.edu/tid/dkq08d00

112 British American Tobacco. Brown \& Williamson preview 1991-1995 [minutes from the CPC meeting held 3 October 1990]. 8 Oct 1990. British American Tobacco. Bates No. 201787487/7489. http:// tobaccodocuments.org/guildford_misc/201787487-7493.html (Accessed $10 \mathrm{Jul}$ 2003)

113 British American Tobacco. Rothmans International: a competitive report. 16 Nov 1992. British American Tobacco. Bates No. 502554531/4545. http:// tobaccodocuments.org/bc_moh/11385.html (Accessed 10 Jul 2003)

114 Bingham P. Excise taxation of tobacco products: key area paper. May 1992. British American Tobacco. Bates No. 301543226/3250. http:// tobaccodocuments.org/guildford_misc/301543226-3250.html (Accessed 14 Jul 2003)

115 Philip Morris. [Presentation notes: slides 1-68 "Australian New Products"]. Jul 1992. Philip Morris. Bates No. 2504107198/7218. http:// legacy.library.ucsf.edu/tid/wwn32e00

116 Philip Morris. [Presentation notes-slides 69-79 Australian retail market: notes for a NY Marketing Meeting]. 1992. Philip Morris. Bates No. 2504107193/7197. http://legacy.library.ucsf.edu/tid/vwn32e00

117 Philip Morris International. Minutes: Philip Morris International Marketing Conference June 18-22, 1989, The Homestead, Hot Springs, VA. 18 Jun 1989. Philip Morris. Bates No. $2500114177 / 4194$. http:// legacy.library.ucsf.edu/tid/ahd42e00

118 Bingham P, Holroyd K. How Marlboro led the pack. Mar 1994. British American Tobacco. Bates No. 502570351/0387. http:// tobaccodocuments.org/health_canada/00100028.html (Accessed $10 \mathrm{Jul}$ 2003)

119 Leo Burnett. Exploratory Marlboro Strategic Research Australia. 10 Feb 1989. Philip Morris. Bates No. 2504057280/7368. http:// legacy.library.ucsf.edu/tid/sot19e00

120 Hulit M. Project Classic-CPC submission. 1 Nov 1989. Philip Morris. Bates No. 2504076970/6970A. http://legacy.library.ucsf.edu/tid/zfi29e00

121 Wisner J. Trip report: Australia/New Zealand, October 25-29, 1982. 15 Nov 1982. Brown \& Williamson. Bates No. 470022029/2032. http:// legacy.library.ucsf.edu/tid/sgz30fo0

122 Housepeters T. [Facsimile to J. Myracle re Marlboro soft pack]. 17 May 1983. Philip Morris. Bates No. 2074867834. http:// legacy.library.ucsf.edu/tid/inv17d00

123 Webb W. Status of the Marlboro Development Programme. 7 Dec 1984 Philip Morris. Bates No. 2023265662/5664. http:// legacy,library.ucsf.edu/tid/gmr98e00

124 Chapman S. Civil disobedience and tobacco control: the case of BUGA UP. Billboard Utilising Graffitists Against Unhealthy Promotions. Tobacco Control 1996;5:179-85. 